\title{
ASSESSMENT OF MACHINE LEARNING TECHNIQUES FOR GOLD PRICE PREDICTIONS
}

\author{
DR. T. CHANDRABAI ${ }^{1}$ \& DR. K. SURESH ${ }^{2}$ \\ ${ }^{1}$ Associate Professor, School of Business, SR University, Warangal (Urban), Telangana, India \\ ${ }^{2}$ Data Scientist, TEK Systems Global Services Pvt. Ltd., Hyderabad, India
}

\begin{abstract}
Machine learning techniques will critically investigate the collected data and it generates the patterns which help to make better decisions.This study applied machine learning techniques such as linear, Random forest and support vector regressions on gold price predictions. These three are very popularmethods to find the variations and patterns in the data.

This paper is focused on identifying the suitable machine learning technique among the selected three methods for future gold price predictions.Time series data of latest 240 months gold prices in rupees is selected for the study. Linear regression, Random forest regression and support vector regression using python are applied to develop the models for price predictions. Among the three methods linear regression is found as a suitable method for the collected data to predict the future gold prices.

KEYWORDS: Machine Learning Techniques, Price Prediction, Regression, Python, Time Series
\end{abstract}

Received: Jun 10, 2020; Accepted: Jun 30, 2020; Published: Aug 01, 2020; Paper Id.: IJMPERDJUN2020559

\section{INTRODUCTION}

Machine learning methods are the algorithms used to analyze the large volumes of data effectively. These will provide a solution to the problem after critical analysis. These techniques or methods are used to find the solutions to the problems in diversified areas such as manufacturing, energy production, price predictions, computational finance and many more.

Gold is the precious metal to the Indian household and will be used as jewelry and as a fixed asset. India is one of the largest gold consuming nations in the world. Indians buy more gold because we treat it as auspicious to our activities. The gold price is increasing year by year and its price during the year 1947 was Rs. 88.62, during the year 1991 was Rs. 3466, and it reached to Rs. 40,000 in the year 2019. Even if the price increases the demand for gold will not decrease. The gold production in India is very less and it unable to meet our demand. So, we are importing it from other countries and it became the second largest import of India.

Some investors will prefer to include this metal in their portfolio to manage their portfolio risk.It is a highly effective portfolio diversifier due to its low to negative correlation with all other major asset classes. It creates a perception of safety among investors. But some other investors treat it as a dead investment. This metal occupied as one of the asset at RBI's reserves account.Today the world's gold stock is about 1, 70,000 metric tons and the world 
produces 168 billion US dollars of gold every year ${ }^{1}$.

\section{REVIEW OF LITERATURE}

\begin{tabular}{|c|c|c|c|}
\hline Author Name & Title of the paper & Methodology & Findings \\
\hline $\begin{array}{l}\text { BanhiGuha\&G } \\
\text { autam } \\
\text { Bandyopadhya } \\
\text { y }(2016)^{3}\end{array}$ & $\begin{array}{l}\text { Gold price forecasting } \\
\text { using ARIMA Model }\end{array}$ & $\begin{array}{l}\text { Monthly gold prices collected } \\
\text { from MCX from Nov. } 2003 \text { to } \\
\text { Jan. } 2014 \text { and forecasted the } \\
\text { price using ARIMA model. }\end{array}$ & $\begin{array}{l}\text { Out of six models } \\
\text { ARIMA }(1,1,1) \text { shown as } \\
\text { best model as it fits the } \\
\text { selected data. }\end{array}$ \\
\hline $\begin{array}{l}\text { Xiaohui Yang } \\
\& \text { Suzhou } \\
\text { (2019) }\end{array}$ & $\begin{array}{l}\text { The Prediction of Gold } \\
\text { Price Using ARIMA } \\
\text { Model }\end{array}$ & $\begin{array}{l}\text { Data collected from world gold } \\
\text { council, is priced in US. Took } \\
1305 \text { observations of daily gold } \\
\text { price from 1/7/2013 to } \\
29 / 6 / 2018 \text {. ARIMA Models are } \\
\text { applied }\end{array}$ & $\begin{array}{l}\text { ARIMA }(3,1,2) \text { appears to be } \\
\text { the best model for predicting } \\
\text { gold price at US. }\end{array}$ \\
\hline $\begin{array}{l}\text { ShahriarShafie } \\
\text { e\&ErkanTopa } \\
(2010)^{5}\end{array}$ & $\begin{array}{l}\text { An overview of global } \\
\text { gold market and gold price } \\
\text { forecasting }\end{array}$ & $\begin{array}{l}\text { Reviewed the world gold } \\
\text { market and the historical trend } \\
\text { of gold prices from January } \\
1968 \text { to December } 2008 \text {. } \\
\text { Investigated the } \\
\text { relationship between gold price } \\
\text { and oil price, global inflation } \\
\text { over the last } 40 \text { years. }\end{array}$ & $\begin{array}{l}\text { Validated model which } \\
\text { estimates the gold price for } \\
\text { the next } 10 \text { years, based on } \\
\text { monthly historical data of } \\
\text { nominal gold price. }\end{array}$ \\
\hline $\begin{array}{l}\text { Antonino Parisi } \\
\text { et., } \mathrm{al}(2008)^{2}\end{array}$ & $\begin{array}{l}\text { Forecasting gold price } \\
\text { changes: Rolling and } \\
\text { recursive neural network } \\
\text { models }\end{array}$ & $\begin{array}{l}\text { Analyzes recursive and rolling } \\
\text { neural network models to } \\
\text { forecast one-step-ahead sign } \\
\text { variations in gold price. }\end{array}$ & $\begin{array}{l}\text { The rolling ward networks } \\
\text { exceed the recursive ward } \\
\text { networks and feed forward } \\
\text { networks in forecasting gold } \\
\text { price sign variation. }\end{array}$ \\
\hline $\begin{array}{l}\text { Werner } \\
\text { Kristjanpoller, } \\
\text { Marcel } \\
\text { C.Minutolo } \\
\text { (2015) } 6\end{array}$ & $\begin{array}{l}\text { Gold price volatility: A } \\
\text { forecasting approach using } \\
\text { the Artificial Neural } \\
\text { Network-GARCH model }\end{array}$ & $\begin{array}{l}\text { Applied an Artificial Neural } \\
\text { Network (ANN) to the } \\
\text { GARCH method generating an } \\
\text { ANN-GARCH, used to } \\
\text { forecast the gold price } \\
\text { volatility (spot and future). }\end{array}$ & $\begin{array}{l}\text { A hybrid model was } \\
\text { analyzed to predict the price } \\
\text { return volatility of the gold } \\
\text { spot and future price. }\end{array}$ \\
\hline $\begin{array}{l}\text { CengizTorama } \\
\text { n, et., al } \\
(2011)^{4}\end{array}$ & $\begin{array}{l}\text { Determination of Factors } \\
\text { Affecting the Price of } \\
\text { Gold: A Study of } \\
\text { MGARCH Model }\end{array}$ & $\begin{array}{l}\text { MGARCH model is tested in } \\
\text { order to find variables affecting } \\
\text { gold prices. }\end{array}$ & $\begin{array}{l}\text { A negative and significant } \\
\text { relationship is found } \\
\text { between the return of gold } \\
\text { and the return of USA } \\
\text { Dollar, the rest of the } \\
\text { variables have no significant } \\
\text { relationship with the return } \\
\text { of gold. }\end{array}$ \\
\hline $\begin{array}{l}\text { AmalenduBhun } \\
\text { ia and } \\
\text { SomnathMukh } \\
\text { uti }(2013)^{1}\end{array}$ & $\begin{array}{l}\text { The impact of domestic } \\
\text { gold price on stock price } \\
\text { indices-An empirical study } \\
\text { of Indian stock exchanges }\end{array}$ & $\begin{array}{l}\text { Assessed the impact of } \\
\text { domestic gold price on stock } \\
\text { price indices of BSE } \\
\text { (SENSEX) and NSE (NIFTY) }\end{array}$ & $\begin{array}{l}\text { Correlation statistics } \\
\text { indicates that BSE and NSE } \\
\text { are positively associated } \\
\text { with domestic gold prices in } \\
\text { the period of study. Multiple } \\
\text { regression test results are } \\
\text { spurious and there is an } \\
\text { existence of serial } \\
\text { correlation as well as }\end{array}$ \\
\hline
\end{tabular}

${ }^{1}$.https://economictimes.indiatimes.com/wealth/invest/why-gold-is-a-deadinvestment/articleshow/62483554.cms?from $=\mathrm{mdr}$ 


\begin{tabular}{|l|l|l|l|}
\hline & & & multicollinearity. \\
\hline
\end{tabular}

\section{STATEMENT OF THE PROBLEM}

Most of the Indian consumers will worry about the drastic change in the gold prices every year. There is a steep increase in gold prices in the current fifteen to twenty years. The price of gold is higher than its historical trend.Most of the research studies on gold price predictions developed ARIMA models. ARIMA is a class of statistical models for analyzing and forecasting time series data. The gold price will change due to several factors and one of the influencing factors is previous value of gold. So, this paper focused on developing regression models using price as dependent variable and 3 months, 9 months moving average prices as independent variables.

\section{OBJECTIVES OF THE STUDY}

- Develop machine learning regression models for gold price predictions and select a suitable model

- Compare the actual and predicted gold prices of the selected data using the selected methods.

\section{HYPOTHESIS}

H0: There is no difference in three models used for predicting the historical gold prices

\section{METHODOLOGY}

Data used for this study is secondary data which is collected from sources. 240 months historical gold prices (month-wise) in India from December 1999 to November 2019 are collected. The sources used to collect the historical gold prices are Ycharts and Index mundi. These websites sites were depended on World Bank and gold council. The collected time series data is analyzed by using machine learning methods such as Linear regression, Random Forest and Support Vector Regression in Python. Moving average method is also applied to calculate moving average price. The regression models developed with these three methods will be compared and find out the suitable model.

\section{ANALYSIS}

Month wise historical gold prices are taken in terms of INR per ounce. This price during December 1999 was Rs. 12309.24 per ounce and during November 2019 was Rs. 105057.2 per ounce. During these twenty years the growth rate in gold price was $753.48 \%$. In the selected data the growth rate for the first 10 years i.e., from December 1999 to December 2009 was $329.85 \%$. This study observed that the first ten years growth rate in the selected time period is less than the second part ten years growth rate. The historical gold pricesare shown in the Chart-1.The lowest and highest difference in actual price and predicted price of the selected three methods were shown in Table-1.

Table 1: Change in actual price and predicted price using the selected methods

\begin{tabular}{|c|c|l|c|}
\hline High/Low & Date & \multicolumn{1}{|c|}{ Method } & Change in actual price and predicted price \\
\hline High & $1 / 8 / 2019$ & Linear Regression & 12343.96 \\
\hline Low & $1 / 12 / 2016$ & Linear Regression & -7034.51 \\
\hline High & $1 / 9 / 2019$ & Random Forest & 19092.51 \\
\hline Low & $1 / 12 / 2016$ & Random Forest & -9333.3164 \\
\hline
\end{tabular}




\begin{tabular}{|c|c|c|c|} 
High & $1 / 9 / 2019$ & Support Vector Regression & 70791.59 \\
\hline Low & $1 / 1 / 2016$ & Support Vector Regression & 36918.45 \\
\hline
\end{tabular}

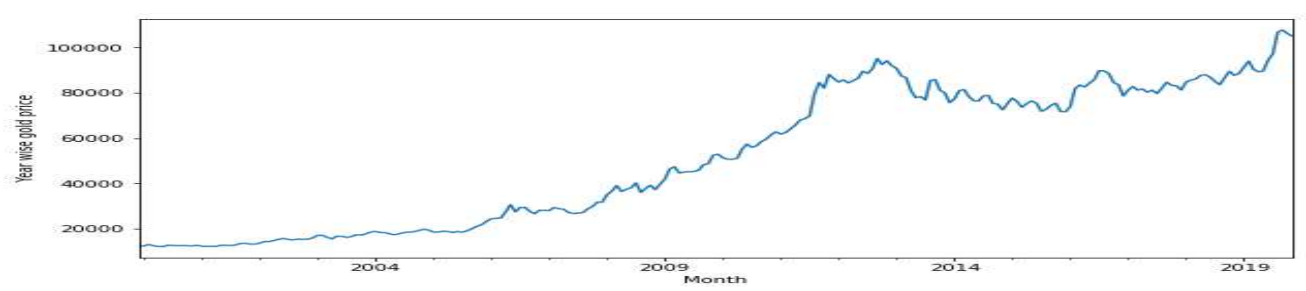

Chart-1: Historical Gold Prices in INR/ounce

First model: It is developed by using linear regression method in python. In this model, the dependent variable is used as gold price and the independent variables used are three months moving average gold price and nine months moving average gold price. The model is represented as:

Gold Price $=a+\beta 1 * 3$ months Moving Average $+\beta 2 * 9$ months Moving Average

\section{Linear Regression}

- $\quad$ Taken month wise gold price fromDecember 1999 to November 2019

- Calculated 3 months and 9 months moving averages

- These two moving averages are considered as independent variables and price is taken as dependent variable

- Data Split - Training $80 \%$ and Testing $20 \%$ for model validation

- Linear Regression model using Python

The following results were found in testing which is shown in Table-2:

- R square 0.992: It is the coefficient of determination can be used to find out the goodness of fit. It means how well the selected data fit the regression model. Its value is lying between 0 and 1 . The tested value is 0.992 , means $99.2 \%$ of data fit the regression model.

- The observed model is:

Gold Price $=666.31+1.26 * 3$ Months Moving Average $-0.26 * 9$ Months Moving Average

- Using this model, predicted price for test data set.

- Based on the following figure for actual price and predicted price, the model is performing well.

Table 2: Linear Regression Model Summary:

OLS Regression Results

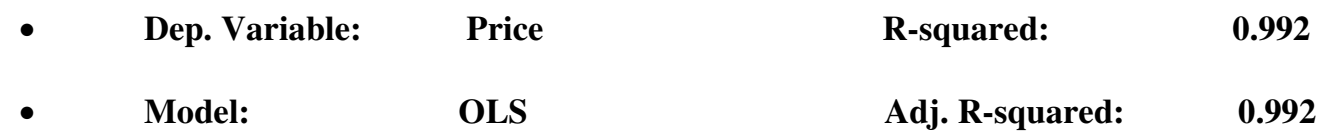


- $\quad$ Method:

- Date:
Least Squares

Fri, 17 Jan 2020
F-statistic:

Prob (F-statistic):
$1.091 \mathrm{e}+04$

2.07e-189

Coefficient std. err $\quad P>|t|$

$\begin{array}{rrrrrr}\text { - } & \text { Const } & 6.3077 & 351.082 & 1.898 & 0.059 \\ \text { - } & \text { S_3 } & 1.2561 & 0.076 & 16.534 & 0.000 \\ \text { - } & \text { S_9 } & -0.2625 & 0.076 & -3.444 & 0.001\end{array}$

- $\quad$ R square: 0.992

- $\quad$ Adj. R square: 0.992

- $\quad$ RMSE: 3659.09

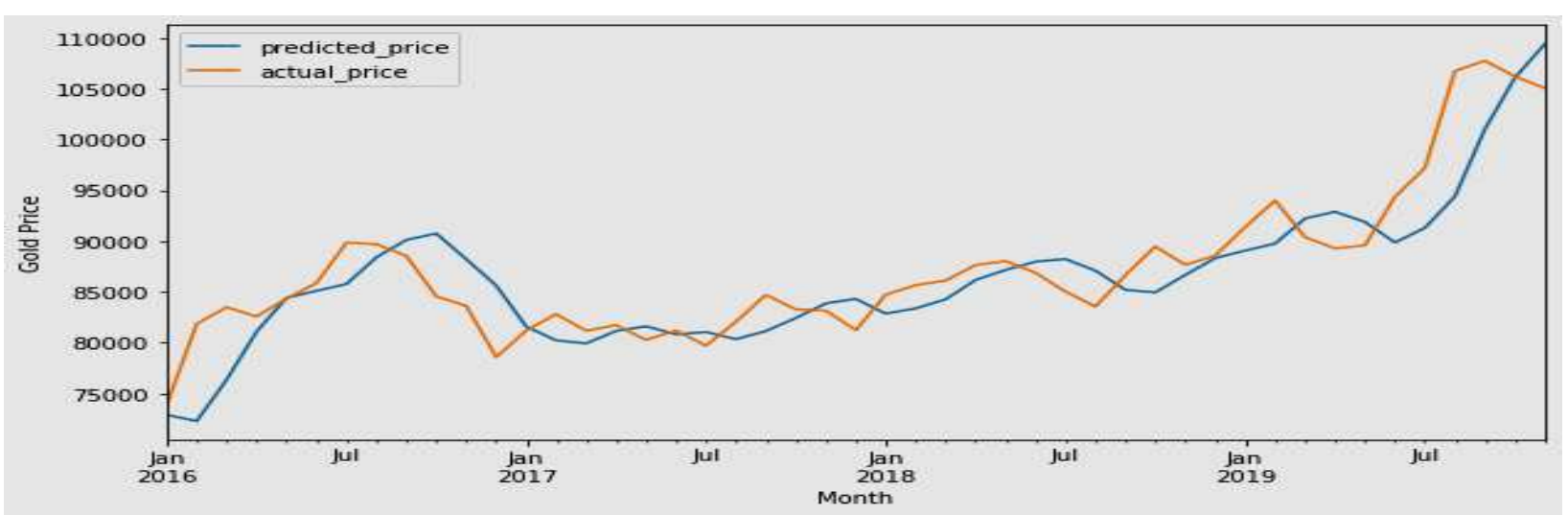

Chart-2: Actual and predicted gold prices using linear regression model using Python

\section{Second Model:}

Random Forest Regression method: It is a supervised learning algorithm which uses ensemble learning method for regression. It operates by constructing a multitude of decision trees at training time and outputting the class.

Training Score: 0.99

Testing Score:0.12

RMSE: 46183698.63.

In common practice the data will split into three sets to build predictive models. Those are training, validation and test. Train the model using training set and test set is used to evaluate the performance of the model.There is a lot of difference between training score ( $\mathrm{R}$ square value) and testing score ( $\mathrm{R}$ square value). The training score is not nearest to the testing score, also the root mean square error value is very high. So, this study found that Random Forest Regression method is not valid for the selected data. The actual and predicted gold prices using this method were shown in chart-2. 


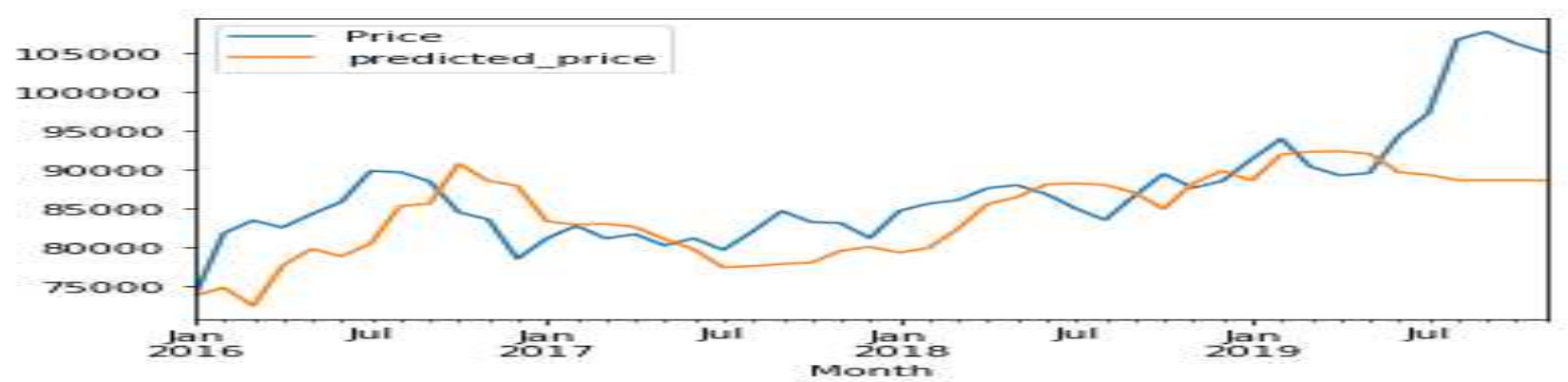

Chart-2: Actual and Predicted gold price using Random Forest Regression Method

\section{Third Model}

\section{Support Vector Regression Result}

Training Score: 0.47

Testing Score: 0.14

RMSE: 2582918142.71

Like Random Forest Regression, The R square value under Training set and Testing set of Support Vector Regression were low. There is no similarity between these two values. Also Very high RMSE value is observed in the testing of this model. So, this model is also not suitable to predict the gold prices for the selected data. The actual and predicted gold prices using this model were shown in chart-3.

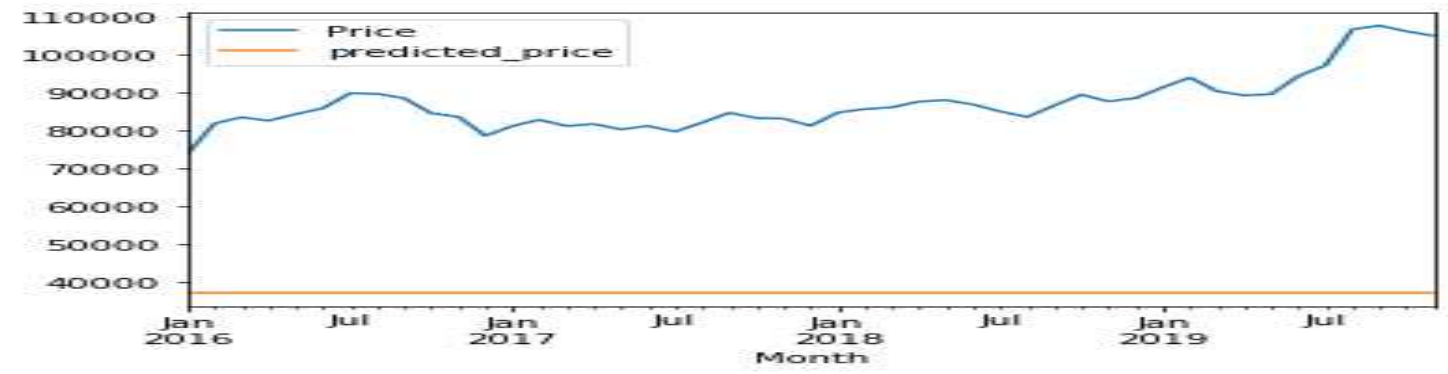

Chart-3: Actual and Predicted gold prices using Support Vector Regression Model

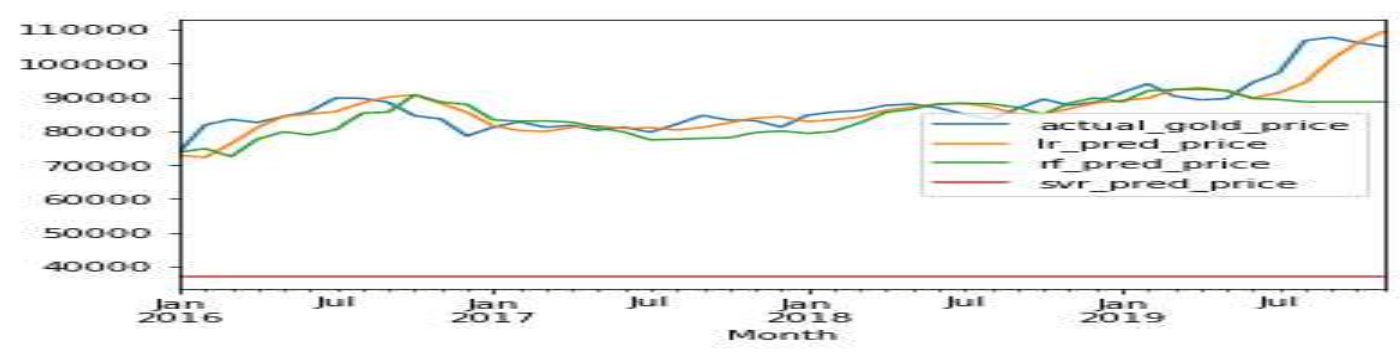

Cart-4: Comparison of models' performance

\section{CONCLUSIONS}

Three regression models such as linear, random forest and support vector were developed in python. The three models observed as different. Among the three models, linear regression model is a suitable model to predict the future gold prices. 
The model is applicable when the gold price will be influenced by the factors which were influenced earlier gold prices.The observed model using linear regression of this study is:

Gold Price = 666.31 + 1.26*3 Months Moving Average -0.26*9 Months Moving Average

\section{REFERENCES}

1. AmalenduBhunia and SomnathMukhuti (2013), The impact of domestic gold price on stock price indices-An empirical study of Indian stock exchanges, Universal Journal of Marketing and Business Research, Vol. 2(2) pp. 035-043.

2. Antonino Parisi, FrancoParisi, David Díaz(2008),Forecasting gold price changes: Rolling and recursive neural network models, Journal of Multinational Financial Management, Volume 18, Issue 5, Pages 477487,https://doi.org/10.1016/j.mulfin.2007.12.002

3. BanhiGuha\&GautamBandyopadhyay (2016), Gold price forecasting using ARIMA Model, Journal of Advanced Management Science Vol. 4, No. 2, pages. 117-121.

4. CengizToraman, ÇagatayBaşarır, Mehmet FatihBayramogluc (2011), Determination of Factors Affecting the Price of Gold: A Study of MGARCH Model, Business Economics Research Journal, Volume 2, Number 4, pages 37-50.

5. Dubey, A. K., et al. "SPSUC: slice, pattern \& style of ubiquitous computing." International Journal of Computer Science Engineering, and Information Technology Research (IJCSEITR) ISSN (P): 2249-6831.

6. Ghosh, Munmun, and Arindam Ghosh. "Consumer buying behaviour in relation to consumption of tea-a study of Pune city." International Journal of Sales and Marketing 3.2 (2013): 47-54.

7. KUMAR, B. SATISH, and Y. KALYAN CHAKRAVARTHY. "PREDICTION OF OPTIMAL TORQUES FROM GAIT ANALYSIS APPLYING THE MACHINE LEARNING CONCEPTS."International Journal of Mechanical and Production Engineering Research and Development (IJMPERD) 9. 4, Aug 2019, 685-698

8. ShahriarShafiee \&ErkanTopa (2010), An overview of global gold market and gold price forecasting, Resources Policy, Volume 35, Issue 3, September 2010, Pages 178-189, https://doi.org/10.1016/j.resourpol.2010.05.004

9. Werner Kristjanpoller, Marcel C.Minutolo (2015), Gold price volatility: A forecasting approach using the Artificial Neural Network-GARCH model, Expert Systems with Applications, Volume 42, Issue 20, Pages 7245-7251.

10. https://doi.org/10.1016/j.eswa.2015.04.058

11. Xiaohui Yang \& Suzhou (2019), The Prediction of Gold Price Using ARIMA Model, Published by Atlantis Press, This is an open access article under the CC BY-NC license

12. (http://creativecommons.org/licenses/by-nc/4.0/)

13. https://www.indexmundi.com/commodities/?commodity=gold\&months $=240 \&$ currency=inr

14. https://goldprice.org/spot-gold.html

15. https://www.macrotrends.net/1333/historical-gold-prices-100-year-chart

16. https://ycharts.com/indicators/gold price in indian rupee 

